\title{
Effects of the Women in Agriculture (WIA) Programme on Welfare of Rural Women in Uvwie Block of the Agricultural Development Programme (ADP), Delta State, Nigeria.
}

\author{
Ovwigho, B.O. ${ }^{1}$, Ifie, P.A ${ }^{2}$ \\ ${ }^{I}$ Department of Agricultural Economics and Extension, Delta State University Asaba Campus, Asaba, Delta \\ State, Nigeria. \\ ${ }^{2}$.Department of Agricultural Education, College of Education, Warn, Delta State, Nigeria
}

\begin{abstract}
The broad objective of the study was to determine the effects of the Women-In- Agriculture programme on the welfare of the participants. Simple random sampling was used in selecting the respondents who were involved in the WIA programme in 2007. The sample was made up of 32 WIA participants consisting Barracks cell (9), Ekpan cell (6), Ukpolokposo (5), Ugbomro cell (7), and PTI cell (5). Data were collected by the use of structured interview schedule. Data were measured by a four-point rating scale and socio-economic status indicators. Data were analyzed by use of simple percentage, mean, Chi square and t-tests. The age distributions were 26-35 years (6.25\%), 36-45 years (1 5.63\%) and over 45 years (78.13\%). The participants agreed that the programme was beneficial because it enhances access to new technologies and group learning $(M=3.56)$, increase access to credit $(M=3.47)$, access to land $(M=2.88)$, and boost production $(M=3.71)$. There was a significant relationship $(P<0.05)$ between memberships of cooperative society, and access to land $\left(\boldsymbol{x}^{2}=\right.$ 7.036, $r=0.47)$, and credit facilities $\left(\boldsymbol{x}^{2}=20.401, r=0.80\right)$. There was a significant difference $(p<0.05)$ in the welfare of participants before and after participating in the WIA programme $(t=-6.941)$. Similar programmes should be established and more women should be encouraged to join the WIA programme so that they could reap the gains of agricultural production through involvement in group farming.
\end{abstract}

Keywords: Effects, participants, rural women, welfare, WIA programme.

\subsection{Background of the study}

\section{Introduction}

In Africa and some developing countries, women play a significant role in production and processing of agricultural products. Rahaman (2008).Sabo (2006), Adisa and Okunade (2005), Meludu et al (1999), and Jiggins et. al; (1997) found that between 60-80\% of agricultural production activities were carried out by women farmers in the continent of Africa. Similarly, FAO (1999) reported that agriculture accounted for $63 \%$ of the total employment in 1997. The report further showed that in sub-saharan Africa, agriculture was still the most important sector for female employment. Ekong (2003) noted that it was not an exaggeration that food security in rural and urban Nigeria depended largely on the women. He stated that the roles of women in agricultural production included land preparation for farming, planting of crops and vegetables, weeding, harvesting, processing of harvested crops and storage, transportation of agricultural produce by head porterage, fishing, fish processing and marketing of sea foods, processing and sale of dairy products and homestead livestock husbandry.

The foregoing underscores the inestimable role of women in agricultural production in country. Unfortunately, women were often classified as invisible farmers while the men were the visible farmers. Akello and Sarr (1999) affirmed that with new challenges arising from political and economic liberalization processes, the demand for gender specific information has been growing on yearly basis. They maintained that this demand came from data users, policy analyst, researchers, academics, rural planners and business people.

According to the Technical Centre for Agricultural and Rural Cooperation, CTA (1993), women constituted about $80 \%$ of the agricultural labor force yet their role in this important economic activity remained obscured. FAO (1999) stated that in sub-Saharan Africa, women farmers, entrepreneurs, and wage earners contributed significantly to the National Gross Domestic Product a nd to national welfare but their effort were hampered by lack of capital, modern implements, distribution facilities and market outlets. In addition, it was common for men to take over the sale of women produce and control women's income. The report further revealed that the contribution of women to household food security has not been fully recognized.

Roy (1977) noted that since women constituted nearly half of the population, they could become a great resource in the development process if they were properly mobilized and organized. Perhaps this admonition together with the variegated problems afflicting women farmers led to establishment of programmes 
like the Women-In-Agriculture programme. The Women-In-Agriculture programme was established mainly to contribute to their welfare and give the women their pride of place in the agricultural development industry. Sabo (2006) asserted that the Women-In-Agriculture programme was designed to address the gender imbalance in agricultural extension delivery. She maintained that the programme evolved from three pilot projects to a nation-wide programme.

According to Agu (2001), and Adisa and Okunade (2005) the Women-In-Agriculture programme was formed in the ADPs by the National Council on Agriculture in 1989. The specific objectives were to: (i) develop gender specific programmes and technologies for women farmers in close collaboration with research institutions, (ii) promote the use of appropriate technologies which would meet the needs of women farmers; (iii) assist in linking women farmers to sources of credit; (iv) support group and individual women activities aimed at increasing the animal protein resources of the country; (v) increase agricultural production and income of women farmers; (vi) improve the skills of women in food processing, utilization and marketing (vii) labororganize women into cooperative societies for purpose of acquiring credit and information; and (vii) encourage women farmers to keep livestock in order to improve the nutritional status of the family.

The women in agriculture programme were inaugurated in the Uvwie block of the ADP in 1992. The study would, however, focus on only those who became members in 2007. The study is further exigent on the fact that no research has been carried out to evaluate the effects of the programme on the welfare of the participants Thus the study would, provide primary information to extension agents, governments and donor agencies on the effects of the WIA programme on the beneficiaries.

\subsection{Objectives of the study}

The broad objective of the study was to determine the effects of the Women-In- Agriculture programme on the welfare of the participants in Uvwie Block of the ADP, Delta State. The specific objectives were to: (i) describe the demographic characteristics of the WIA participants; (ii) ascertain the benefits of the WIA programme and (iii) determine the influence of membership of cooperative society on access to land, credit facilities and labor; and (iv) determine the effects of the WIA programme on the welfare of the women.

\subsection{Hypotheses}

Two null hypotheses were tested at 0.05 level of significance

$\mathrm{HO}_{1:}$ There is no significant relationship between membership of cooperative society and access to land, credit facilities and labor.

$\mathrm{HO}_{2:}$ There is no significant difference in the possession of selected welfare indicators of the WIA participants before 2007 and after 2012

\section{Materials and methods}

\subsection{Sampling technique and sample size}

Simple random sampling was used in selecting the respondents who became involved in the WIA programme in 2007. Fifty (50) percent corresponding to five cells were randomly selected from the ten cells in the Uvwie ADP block. The population of WIA participants in the five cells in 2007 was 64 consisting of Barracks cell (18), Ekpan cell (12), PTI cell (10), Ukpolokposo cell (10) and Ugbomro cell (14). Fifty percent of the participants were randomly selected from each cell. This gave a sample size of 32 consisting Barracks cell (9), Ekpan cell (6), Ukpolokposo (5), Ugbomro cell (7), and PTI cell (5)..

\subsection{Method of data collection and analysis}

Data were collected by the use of structured interview schedule. The interview schedule measured demographic characteristics, benefits of the WIA programme, access to production resources, membership of cooperative society and effects of the programme on participants. Data were analyzed by use of simple percentage, mean, Chi square and t-tests

\subsection{Measurement of variables}

The benefits of the WIA programme were measured by a four-point rating scale. Five (5) positive statements were constructed and scored as follows: Strongly Disagree (1), Disagree (2), Agree (3) and Strongly Agree (4). The total nominal value divided by 4 gave a mean value of 2.50 . A mean value of below and above 2.50 was regarded as disagree and agree respectively. Measurement of welfare was done using twelve (12) indicators of welfare contained on the socio-economic status scale constructed by Ovwigho (2011). The indicators and their scores were presented in Table 1. The total score of a respondent on the scale before 2007 and by 2012 were used to measure the welfare of the participants before and after the WIA intervention programme. 


\subsection{Demographic characteristics}

\section{Results and discussion}

Five demographic characteristics namely age, marital status, educational level, primary occupation, and secondary occupation were measured. The age distributions were $26-35$ years $(6.25 \%), 36-45$ years $(15.63 \%)$ and over 45 years (78.13\%). This showed that majority of the respondents were above 45 years old. Marital statuses of the respondents were married (65.63\%) and widow (34.38\%). There was no single woman among the respondents. Majority of the respondents had no formal education (65.63\%), primary education (28.13\%), and Secondary School Certificate (6.25\%). All the participants had farming as their primary occupation (100.00\%). The secondary occupations were trading (37.50\%), teaching (15.63\%) and others $(46.88 \%)$.

\subsection{Benefits of the WIA programme :}

The respondents were asked to rate the benefits of the programme since they became members (Table 2). The participants agreed that the programme was beneficial because it enhances access to new technologies and group learning $\mathrm{M}=3.56)$, increase access to credit $(\mathrm{M}=3.47)$, access to land $(\mathrm{M}=2.88)$, and boost production $(M=3.71)$. The participants disagreed that the programmemme enables them to hire labor $(M=1.78)$. From the results it could be concluded that the programme was beneficial to the participants. The WIA participants worked in groups and onteract with one another. These findings corroborate that of Ladele (1994) stated that categorizing farmers into groups have many obvious advantages in agricultural extension delivery. These advantages included: increased coverage of farming communities thereby improving the dissemination of extension messages and agricultural innovations; allows for participation of more people in farming activities; help members acquire skills and education; help to provide support services to compliment the education functions of the extension agents; and help to reduce costs per head in the production process.. Similarly, Windapo and Afolayan (2005) agreed that disaggregating farmers into groups allowed them to express their constraints and opinions freely.

\subsection{Access to production resources}

The study investigated the extent to which production resources were available. The three production resources analyzed were access to land, credit facilities and labor (Table 3). The WIA programme gave the participants adequate access credit facilities (65.6\%) and access to land was fairly adequate (46.9\%). Access to labor was not adequate $(6.3 \%)$. This meant that the programme afforded the participants the opportunity to have access to land and credit facilities. Labor was provided by the farmers and families to save cost of production. The programme has made many women to have access to production resources. In the past, agricultural extension services and production incentives were targeted primarily at male farmers thereby denying the women of the resources needed to boost agricultural production. Jiggins et al; (1997) observed that agricultural extension activities traditionally focused on increasing production of cash crops by providing men with training, information and access to inputs and services. The influence of cooperative membership on access to production resources was further tested by the use of Chi square test (Table 4). There was a significant relationship ( $\mathrm{P}<$ $0.05)$ between memberships of cooperative society, access to land $\left(\boldsymbol{x}^{2}=7.036, \mathrm{r}=0.47\right)$ and credit facilities ( $\left.x^{2}=20.401, r=0.80\right)$. There was no significant relationship $(\mathrm{p}>0.05)$ between membership of cooperative society and access to labor $\left(\boldsymbol{x}^{2}=3.556, \mathrm{r}=0.33\right.$ ) Membership of cooperative society gave the impetus to the participants to acquire production resources. Thus one of the cardinal objectives germane to organize women into cooperative societies for the purpose of credit mobilization and dissemination of information was achieved by the WIA programme. Emefesi et.al. (2004) advised that proper attention should be paid to the cooperative societies organized by Women-In-Agriculture (WIA) programme to enable them derive the benefits of access to agricultural production resources and increase income. Claxton (2000) noted that cooperative membership give women farmers a new sense of direction, hope and empowerment because of the ability to cater for their family's needs and economic growth of the community as a whole. He further stated that cooperatives have the advantage of increasing agricultural production of women, bettering their lifestyle and eradicating diseases, which has direct effect on their living standard

\subsection{The effects of WIA Programme on welfare of participants}

The effects of the WIA programme on the welfare of participants were measured with twelve indicators contained on the socio-economic status scale constructed by Ovwigho (2011) (see Table 1). The possession scores of the items before 2007 and by 2012 were compared by the use of t-test (Table 5) There was a significant difference $(\mathrm{p}<0.05)$ in the welfare of participants before and after participating in the WIA programme $(t=-6.941)$. The meant that the WIA programme contributed positively to the welfare of the women. Katherine et.al (1994) stated that the WIA has contributed substantially to poverty alleviation and household food security especially in the rural areas Ogunlela and Mukhtar (2009) affirmed that women contribute tremendously to agricultural output but unfortunately they hardly, until recently, benefited from 
agricultural incentives and innovation because of economic suppression and social and traditional practices which undermine the constitutional provisions on the equality of men and women. It is gratifying, therefore, that the WIA programme has come to the aid of women farmers..

\section{Conclusion and recommendation}

The study established a significant relationship between memberships of cooperative society, and access to land and credit facilities. There was a significant difference between the welfare of participants before and after the WIA intervention programme. The WIA programme was beneficial to the participants. It contributed immensely to increase in the welfare of the participants The women had access to land and credit facilities. Similar programmes should be established and more women should be encouraged to join the WIA programme so that they could reap the gains in agricultural production.

\section{References}

[1] Adisa, B. and Okunade, E. Q. 2005. Women in agriculture and rural development. In Adedoyin, S. E. (ed). Agricultural extension in Nigeria. Ilorin: Agricultural Extension Society of Nigeria pp. 69-77.

[2] Agu, V.0. 2000. The Nigeria women in agriculture programme: projects coordinating units perspective. A paper presented at the nigeria women in agriculture review workshop organized by the World Bank FACU and ADPs.

[3] Akello, G. and Sarr, F. 1999. The economic role of women in agricultural and rural development. the promotion of income generating activities. CTA Special Annual Report 1999.

[4] Claxton, A. 2000. Women and development. in: together. A Journal of World Vision Partnership, 66: 17-22

[5] Ekong, E.E. 2003. An introduction to rural sociology. Uyo: Dove Educational Publishers.

[6] Emefesi, B.O.. Hamidu B. M and Haruna U. 2004. Role of women farmers' cooperative societies in agricultural production: a case study of Bauchi local government area of Bauchi State. A Paper Presented at the Farm Management Association of Nigeria

Conference at Abuja, held between October $19 \& 24,2004$

[7] Food and Agriculture Organization,FAO 1999. Filling the data gap: gender sensitive statistics for agricultural development. Rome: FAO.

[8] Jiggins, J. Samanta, R.K. and Olawoye, J.E. 1997. Improving women farmers access to extension services. In: Swanson, BE., Bentz, R.P. and Sofranko, A.U. (eds). Improving Agricultural Extension: A reference manual. Rome: FAQ pp.73-81.

[9] Katherine, S.A., Halin, M..and Dapline, S, 1994. Raising the productivity of women farmers in sub-Saharan Africa.World Bank Discussion Papers

[10] Ladele, A.A.1994. Dynamics of agricultural extension services structure and policy: the need for group extension in sustainable agricultural technology transfer in Nigeria. In: Afolayan S.Q. and Akinbode, 1.A (eds). Proceedings of the Inaugural Conference of the Agricultural Extension Society of Nigeria, pp. 57-63.

[11] Meludu, N.T., lfie, P.A., Akinbile, L.A., and Adekoya, E.A. 1999. The role of women in sustainable food security in Nigeria: A Case Study of Udu Local Government Area of Delta State. Journal of Sustainable Agriculture, 15:1:67-97.

[12] Ogunlela, Y. I.. and Mukhtar, A. A. 2009. Gender Issues in Agriculture and Rural Development in Nigeria: The Role of Women. Humanity and Social Sciences Journal $4 \quad$ (1): $19-30$

[13] Ovwigho, B. O. 2011. Construction of a socio-economic status of heads of farm families in north agricultural zone of Delta State, Nigeria. Journal of Human Ecology, 33 (2): 113-118

[14] Rahaman, S. A. 2008. Women's involvement in agriculture in Northern and Southern Kaduna State. Journal of Gender Studies,

[15] Roy, R, B. 1977, Women in Bangladesh: \The Role of Women in Contributing to Family Income. Bangkok Thailand: FriedrichEbert-Stiftung

[16] Sabo, E. 2006. Participatory assessment of the impact of women in agriculture programme of Borno State, Nigeria. Journal of Tropical Agriculture. 44:82-85.

[17] Technical Centre for Agricultural and Rural Cooperation, CTA 1993. Women's rightful place. Spore, 105:65

[18] Windapo, O. and Afolayan, S.O. 2005. Group dynamics and leadership in agricultural extension. In: Adedoyin, S.F.(ed). Agricultural extension in Nigeria. Ilorin: Agricultural Extension Society of Nigeria 
Table 1: A scale to measure welfare status of WUA participants

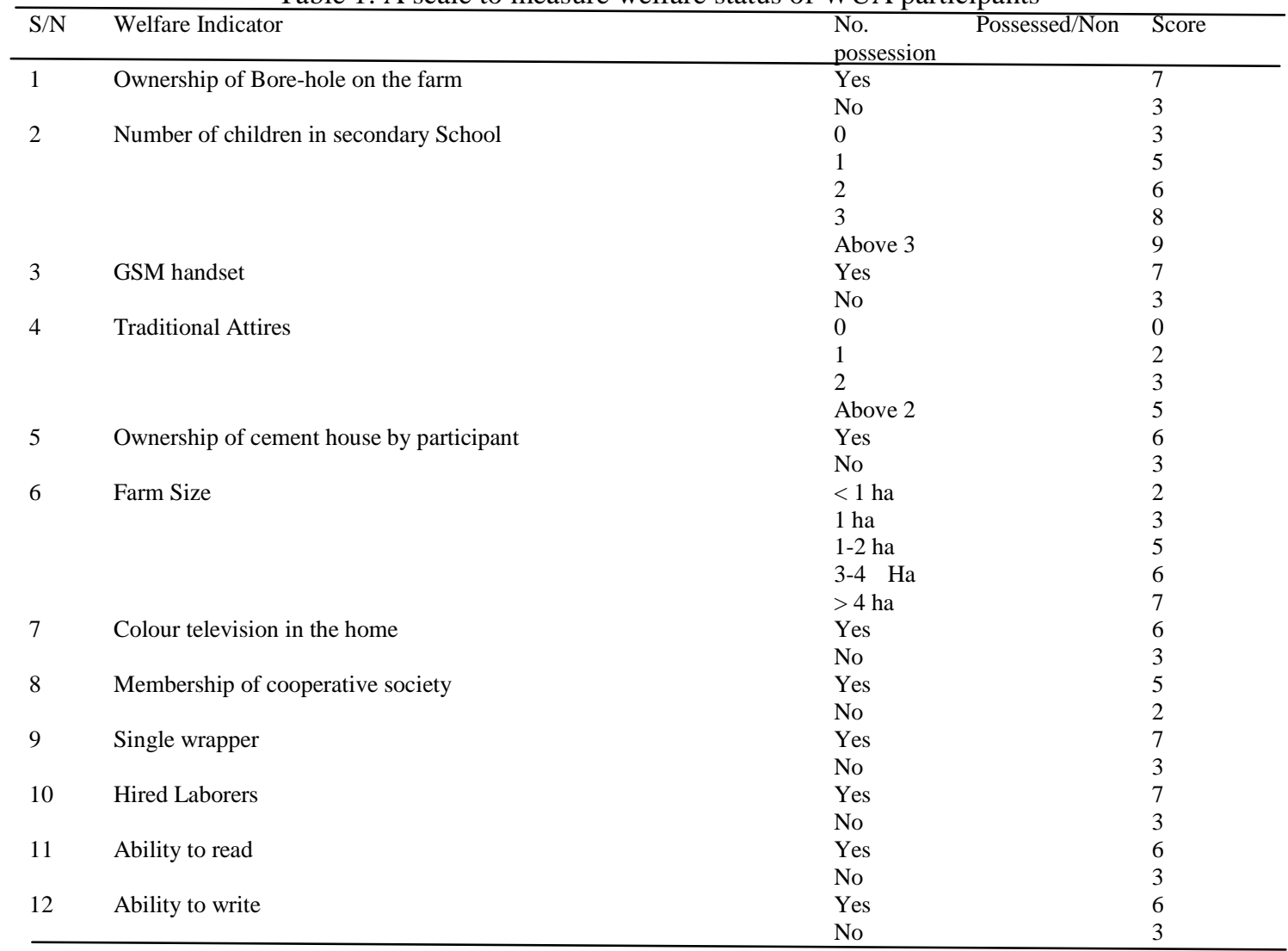

Source: Adapted from Ovwigho (2011). Construction of a Socio-economic status scale

Table 2: Some rated benefits of the WIA programme

\begin{tabular}{|c|c|c|c|}
\hline $\mathrm{S} / \mathrm{N}$ & Item & Mean Score & Remarks \\
\hline 1 & Enhances access to new technologies and group learning & 3.56 & Agree \\
\hline 2 & Increases access to credit & 3.47 & Agree \\
\hline 3 & Increases access to land & 2.88 & Agree \\
\hline 4 & It enables participants to engage hired labor & 1.78 & Disagree \\
\hline 5 & It helps to boost production & 3.71 & Agree \\
\hline \multicolumn{4}{|c|}{ Table 3: Access to land credit facilities and labor } \\
\hline \multicolumn{2}{|c|}{ Access to Land } & $17(53.1)$ & Not adequate \\
\hline \multicolumn{2}{|c|}{ Access to Credit } & 11(34.4) & Adequate \\
\hline \multicolumn{2}{|c|}{ Access Labor } & $30(93.7)$ & Not adequate \\
\hline
\end{tabular}

NB: Above $50 \%$ yes $=$ adequate $40-50 \%$ yes $=$ fairly adequate, and less than $40 \%=$ inadequate In parenthesis $=$ percentage

Table 4: Relationship between membership of cooperative society and access to land credit and labor

\begin{tabular}{lllll}
\hline Variables & $x^{2}$ & DF & Phi Coefficient \\
\hline Access to Land & 7.036 & 1 & 0.47 & Sig. \\
Access to Credit facilities & 20.401 & 1 & 0.80 & 0.01 \\
Access to Labor & 3.556 & 1 & 0.33 & 0.00 \\
\hline
\end{tabular}

Table 5: Mean differences before and after participating in the WIA programme

\begin{tabular}{llllll}
\hline Variable & Mean & Std. Dev & St. error of Mean & t value & DF \\
\hline Before involvement & 45.161 & 9.1088 & 1.63599 & -6.941 & 30 \\
After involvement & 56.516 & & & 0,000 & \\
\hline
\end{tabular}

